\title{
The Optimised Statistical Model for Enzymatic Hydrolysis of Tapioca by Glucoamylase Immobilised on Mesostructured Cellular Foam Silica
}

\author{
Joni Agustian*, Lilis Hermida \\ Department of Chemical Engineering, Universitas Lampung, Jl. Prof. S. Brodjonegoro No. 1, \\ Gedong Meneng, Rajabasa, Bandar Lampung 35145, Lampung, Indonesia
}

Received: 15 th August 2018; Revised: $4^{\text {th }}$ February 2019; Accepted: $6^{\text {th }}$ February 2019; Available online: 30th April 2019; Published regularly: 1st August 2019

\begin{abstract}
Enzymatic hydrolysis of starches using free glucoamylase to reducing sugars have difficulties in recovering and recycling of the enzyme, hence immobilisation on inert supports were widely studied. However, effectiveness of the immobilised glucoamylase were merely observed only on soluble starches. It was considered a valuable thing to know performance of glucoamylase on Mesostructured Cellular Foam (MCF) silica in hydrolysing of tapioca. An optimised study on enzymatic hydrolysis of tapioca using glucoamylase on MCF silica (9.2T-3D) and its kinetics were described including justification of the predicted model as it was required to develop in large scale operations. Central Composite Design was used to model the process by studying effects of three factors on DE values after enzyme immobilisation. Immobilisation of glucoamylase on this support gave up to $82 \%$ efficiency with the specific activity of $1,856.78 \mathrm{U} \cdot \mathrm{g}^{-1}$. Its used to hydrolysis of tapioca resulted DE values of $1.740-76.303 \%(\mathrm{w} / \mathrm{w})$ where the highest $\mathrm{DE}$ was obtained at $\mathrm{pH}$ of 4.1 , temperature of $70{ }^{\circ} \mathrm{C}$ and agitation speed of $140 \mathrm{rpm}$. The optimisation produced a polynomial quadratic model having insignificant lack-of-fit and low standard deviation, so that it was applicable and reliable in simulating the DE with only $0.80 \%$ of data were not described. Temperature affected the process highly, but the buffer $\mathrm{pH}$, agitation speed and factorial interactions were considered not important. $K_{M}$ value for immobilised enzyme was better than the free glucoamylase, however, its reaction rate was slower than the free glucoamylase catalysis. Copyright $\mathbb{C}$ 2019 BCREC Group. All rights reserved
\end{abstract}

Keywords: Enzymatic Hydrolysis; Glucoamylase Immobilisation; Mesostructured Cellular Foam Silica; Tapioca; Central Composite Design

How to Cite: Agustian, J., Hermida, L. (2019). The Optimised Statistical Model for Enzymatic Hydrolysis of Tapioca by Glucoamylase Immobilised on Mesostructured Cellular Foam Silica. Bulletin of Chemical Reaction Engineering \& Catalysis, 14(2): 380-390 (doi:10.9767/bcrec.14.2.3078.380-390)

Permalink/DOI: https://doi.org/10.9767/bcrec.14.2.3078.380-390

\section{Introduction}

In the producing industries of ethanol, glucose, monosodium glutamate, nucleotides and curdlan, hydrolysis of tapioca (Manihot esculen-

* Corresponding Author.

Email: joni.agustian@eng.unila.ac.id (J. Agustian); Telp: +62-721-704947, Fax: +62-721-704947 $t a)$ starch to give reducing sugars must be conducted at first before microbial fermentation of the substrate into these fermentative product(s) takes place. Besides acidic-based processes, enzymatic hydrolysis of tapioca is often conducted using free glucoamylase. The uses of this enzyme type often have difficulties in recovering and recycling of it back to the hydrol- 
ysis process. Therefore, immobilisation of free glucoamylase onto inert insoluble supports is studied highly. Previous experiments showed that various materials were developed to support immobilisation of free glucoamylase, such as: nanomagnetic compounds, carbon, cellulose beads, montmorillonite, polymers, gelatine, and alginate via adsorption, covalent bond, entrapment, and/or encapsulation method [1-12].

The siliceous-based compounds were one of the studied supports. For example, mesoporous silica particles were used to encapsulate free glucoamylase, which effectively hydrolysed water soluble carbohydrate and could be used for many cycles of the process [13]. Glucoamylase immobilised on mesostructured cellular foam (MCF) silica also performed well by having high activity during hydrolysis of soluble starch [14]. Later, high performance of the soluble starch hydrolysis was obtained using glucoamylase immobilised on large ordered siliceous materials such as SBA-15 and mesoporous silica either by adsorption or by covalent bonds $[15,16]$.

As effectiveness of all silica-based supports were proved on soluble starches, it is considered a valuable thing to observe performance of glucoamylase immobilised on the MCF silica in hydrolysing of water insoluble starches. Therefore, an optimised study on the enzymatic tapioca starch hydrolysis using the MCF silica (9.2T-3D)-based glucoamylase is herewith reported including the process justification as a predicted model is required to develop the large scale operations. Kinetics of the process is also determined.

\section{Materials and Methods}

\subsection{Materials}

Poly(ethylene glycol)-block-poly(propylene glycol)-block-poly(ethylene glycol) (PEG-PPGPEG (no. 435465), 1,3,5-trimethylbenzene (>98\%), orthosilicic acid tetraethyl ester $(>99 \%)$ and acetic acid sodium salt ( $>98 \%$ ) were bought from Sigma Aldrich via a domestic supplier. Fluoroammonium ( $>98 \%$ ), hydrogen chloride $(37 \%)$, sodium monohydrogen phosphate (>99\%), dextrose (>99\%), potassium biphosphate $(>99 \%)$ and dinitrosalicylic acid (DNS) $(>98 \%)$ were Merck products. Glucoamylase LYPH170122 (30,000 U.g-1) was supplied by Xi'an Lyphar Biotech Co. Ltd. (China). Local tapioca starch was used. The support was synthesized following the procedures arranged by Hermida et al. [17].

\subsection{Enzyme Immobilisation}

$60 \mathrm{mg}$ enzyme and $500 \mathrm{mg}$ support were mixed with $30 \mathrm{~mL} 100 \mathrm{mM} \mathrm{pH} 5.5$ Sorensen $\mathrm{PO}_{4}$ buffer. This mixture was shaken at 100 $\mathrm{rpm}$ and $30^{\circ} \mathrm{C}$ for 5 (five) hours. After filtration of the mixture, filtrate was kept temporarily in refrigerator for protein analysis. Residue of the process was washed with $100 \mathrm{mM} \mathrm{pH} 5.5$ Sorensen buffer $(3 \times 50 \mathrm{~mL})$ where filtrate of the washing process was also kept in refrigerator before the protein checking. The residue was dried in a desiccator at room temperature overnight and then stored in refrigerator. Enzyme load $(q)$ was calculated as follows:

$$
q=\frac{\left(C_{o}-C_{t}\right) \times V}{W}
$$

where $C_{o}$ is initial free enzyme concentration $(\mathrm{mg} \mathrm{mL}-1), C_{t}$ is final free enzyme concentration $\left(\mathrm{mg} \mathrm{mL} \mathrm{m}^{-1}\right), V$ is reactor working volume $(\mathrm{mL})$, and $W$ is weight of support (g).

\subsection{Specific Activity of Enzyme}

A method described by Milosavic et al. [6] was adopted. A stock solution was prepared by dissolving $4 \mathrm{~g}$ soluble starch in $100 \mathrm{~mL} 50 \mathrm{mM}$ pH 4.5 sodium acetate buffer. Then, two flasks containing $25 \mathrm{~mL}$ of the stock solution were prepared. The flasks were shaken in a water bath shaker at $140 \mathrm{rpm}$ and $60{ }^{\circ} \mathrm{C}$. After this temperature was reached, $50 \mathrm{mg}$ immobilised enzyme and $25 \mathrm{mg}$ free enzyme were added into the $1^{\text {st }}$ and $2^{\text {nd }}$ flasks to initiate hydrolysis of the starch. During the process, samples were withdrawn every five minutes for a 30 minutes period and centrifuged at $3000 \mathrm{rpm}$ for 3 minutes before DNS analysis. One enzyme unit (U) was the amount of enzyme, which released reducing carbohydrates equivalent to one $\mu$ mole glucose from soluble starch in one minute.

\subsection{Experimental Design}

Central Composite Design (CCD) of experiment was used to determine the statistical model of tapioca starch hydrolysis by immobilised glucoamylase on MCF silica (9.2T-3D). Three operational factors were studied in five levels (Table 1). Design Expert ${ }^{\circledR}$ v. 6.0.6 was used to design and analyse the results. Dextrose equivalent (DE) was set as response.

\subsection{Enzymatic Hydrolysis Process}

$30 \mathrm{~mL} 0.1 \mathrm{M}$ sodium acetate buffer (Table 1 provided the $\mathrm{pH}$ value) were placed in several 
$100 \mathrm{~mL}$ Erlenmeyer flasks. Then, 3\% (w/v) of tapioca starch were dissolved in each flask. The flasks were shaken in a water bath shaker at certain agitation speed and temperature according to the operating conditions provided by CCD. After the temperature was reached, 400 mg immobilised enzyme was put into each flask to begin the hydrolysis process for 8 (eight) hours. Initial and final sample were collected to measure the DE values using DNS method.

\subsection{Kinetic Constants}

$V_{\max }$ and $K_{M}$ was investigated by varying concentration of tapioca $(1-5 \% \mathrm{w} / \mathrm{v})$ in $30 \mathrm{~mL}$ $0.1 \mathrm{M}$ sodium acetate buffer $\mathrm{pH}$ 4.3. The process was set at $72.4^{\circ} \mathrm{C}$ and $137 \mathrm{rpm}$ for 3 (three) hours. $400 \mathrm{mg}$ of enzyme was used. Samples were withdraw every half an hour for the DNS analysis. The initial rate data were processed with Chem SW Enzyme Kinetics! Pro.

\subsection{Estimation of Protein and Glucose}

The protein content was estimated using Pierce $^{\mathrm{TM}}$ BCA protein assay kit. The hydrolysis of starch to glucose was followed by DNS analysis method. Shimadzu UV-VIS 1800 spectrometer was used to observe the protein and glucose content.

\subsection{Characterization (FTIR, SEM)}

Nitrogen adsorption-desorption isotherm data were obtained using a Quanta-chrome Autosorb 1C automated gas sorption analyzer operated at liquid nitrogen temperature to estimate average cell pore size, average window pore size, specific pore volume and specific surface area using Barrett-Joyner-Halenda (BJH) method and Brunauer-Emmett-Teller (BET) method. The enzyme and support were further observed with Zeiss EVO field emission scanning electron microscope (SEM) equipped with an Oxford INCAX act, energy dispersive X-ray (EDX) microanalysis system to obtain SEM images and chemical compositions. Samples were also observed using Frontier Perkin Elmer FTIR unit.

\section{Results and Discussions}

\subsection{Glucoamylase on Support}

Approximately $48.46 \mathrm{mg}$ of the supplied free glucoamylase was adsorbed per $1 \mathrm{~g}$ of support $(\sim 82 \%)$. It was considered quite well. As the glucoamylase size $(\sim 80 \AA)$ is lower than the support size (the support had specific surface area $\left(S_{\text {BET }}\right)$ of $378 \mathrm{~m}^{2} \cdot \mathrm{g}^{-1}$, cell diameter $\left(d_{\text {cell }}\right)$ of $235 \AA$, pore volume of $2.12 \mathrm{~cm}^{3} \cdot \mathrm{g}-1$, window diameter of $158 \AA$ ), the free enzyme had high areas to attach not only on the outer surfaces, but also in the inner parts of the silica. In comparisons, nanoparticles carriers produced lower to high glucoamylase loads. For examples, the carboxyl functioned magnetic nanoparticles (diameter of $\pm 9 \mathrm{~nm}$ ) [2], functionalised magnetic nanoparticles (diameter <30 nm) [18] and functionalised $\mathrm{Fe}_{3} \mathrm{O}_{4}$-chitosan hybrid (average diameter $200 \mathrm{~nm}$ ) [19] gave the enzyme loads of $12-120 \mathrm{mg}$ enzyme per gram support. However, though nanoporous materials had similar size, they tended to give relatively lower loads. Functionalised magnetic graphite nanosheets (pore sizes of $\sim 11.71 \mathrm{~nm}, S_{\text {BET }}=60.07 \mathrm{~m}^{2} \cdot \mathrm{g}^{-1}$ ) [20], poly(amidoamine) magnetic carbon nanotubes (MCNTs-PAMAM) (CNTs diameters of 20-30 nm) [21], and $\mathrm{Fe}_{3} \mathrm{O}_{4} @$ clay composites (pore sizes of 13.17-22.06 nm, $S_{\text {BET }}=36.2-48.5$ $\mathrm{m}^{2} / \mathrm{g}$ ) [22] absorbed only 9-21 mg glucoamylase per gram support. The mesoporous-type carriers had similar performances. Functionalised FeSBA-15 (pore diameter of 6-11 nm, surface area of $\geq 550 \mathrm{~m}^{2} / \mathrm{g}$ ) generally absorbed 10-22 mg glucoamylase per gram support [3]. Mesoporous carbons (Sibunit (pore diameter of 18 $\left.\mathrm{nm}, 555 \mathrm{~m}^{2} / \mathrm{g}\right)$, bulk CFC (11 nm, $\left.162 \mathrm{~m}^{2} / \mathrm{g}\right)$, activated carbon $\left(4 \mathrm{~nm}, 1296 \mathrm{~m}^{2} / \mathrm{g}\right)$ showed a little higher of enzyme absorption i.e. 5-24 mg enzyme per gram carbon [4]. Modified macroporous copolymer of glycidyl methacrylate and ethylene glycol dimethacrylate (poly(GMA-co-EGDMA)) with pore size of 53 $\mathrm{nm}$ and surface area of $50 \mathrm{~m}^{2} / \mathrm{g}$ provided $35 \%$ immobilisation yield [7]. Milosavic, Prodanovic, Jovanovic, and Vujcic [6] obtained enzyme loads as high as $190 \mathrm{mg}$ glucoamylase per

Table 1. The factors and level of the experimental design

\begin{tabular}{|c|c|c|c|c|c|c|}
\hline \multirow{2}{*}{ Factor } & \multirow{2}{*}{ Symbol } & \multicolumn{5}{|c|}{ Level } \\
\hline & & $-\alpha$ & Low & 0 & High & $+\alpha$ \\
\hline Temperature $\left({ }^{\circ} \mathrm{C}\right)$ & $x_{1}$ & 61.6 & 65 & 70 & 75 & 78.4 \\
\hline Buffer $\mathrm{pH}$ & $x_{2}$ & 4.1 & 4.3 & 4.6 & 4.9 & 5.1 \\
\hline Agitation speed (rpm) & $x_{3}$ & 123 & 130 & 140 & 150 & 157 \\
\hline
\end{tabular}


gram poly(GMA-co-EGDMA). Functionalized mesostructured cellular foam silica (pore diameter of 22-25 nm, wall diameter of $12-14 \mathrm{~nm}$, surface area of $316-620 \mathrm{~m}^{2} / \mathrm{g}$ ) yielded only 3.3 $26.7 \%$ immobilised glucoamylase [14].

Immobilisation of the free enzyme on the support was proved by SEM and FTIR analysis. Observations on the SEM results showed an important change on the support. The original support had smooth surfaces as shown in Figure 1-A. However, after the enzyme immobilisation was conducted, rough surfaces were observed (Figure 1-B), which indicated the presence of enzyme on it. The FT-IR spectrum of the original MCF silica (9.2T-3D) (Figure 2) showed vibrations at $1300 \mathrm{~cm}^{-1}$ and $850 \mathrm{~cm}^{-1}$ with peak at $1061 \mathrm{~cm}^{-1}$ to indicate the $\mathrm{Si}-\mathrm{O}-\mathrm{Si}$ stretching presence. These vibrations were also found on the immobilized enzyme spectrum, but an additional vibration $1962 \mathrm{~cm}^{-1}$ was discovered. The new vibration confirmed the $\mathrm{C} \equiv \mathrm{N}$ or $\mathrm{C} \equiv \mathrm{C}$ bounds [23]. As glucoamylase is a protein consisting of a single polypeptide chain of amino acids, this vibration indicated the presence of amino acid on the support.

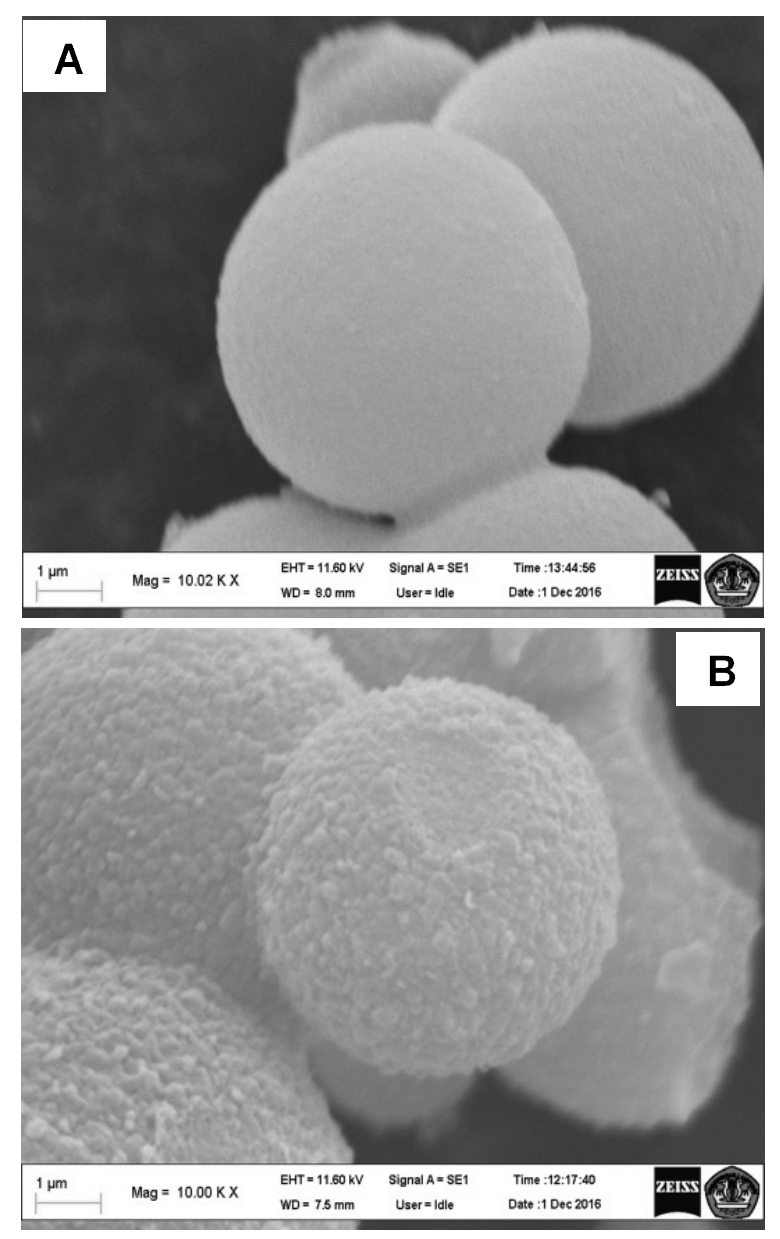

Figure 1. SEM images of supporting material (A) and glucoamylase on support (B)
Analysis of the specific activity revealed that reduction of activity occurred after the immobilisation process. The free glucoamylase activity was 30,335 U.g. ${ }^{-1}$, but the immobilised type had the specific activity of $1,857 \mathrm{U}^{\mathrm{g}}{ }^{-1}$. In general, immobilisation of the free glucoamylase on inorganic support tended to reduce its initial specific activity. Glucoamylase adsorbed on Sibunit retained up to $20 \%$ of the initial activity of the dissolved enzyme [4,24]. Lower glucoamylase specific activity $(<10 \%)$ was obtained when it was immobilised on polymeric compounds $[6,7,25]$. The specific activity as high as $55 \%$ for the immobilised glucoamylase was achieved when magnetic clays were used as supports [22]. These reductions could be caused by conformational changes on the enzyme structures during the immobilisation process as some enzyme active sites are difficult to be accessed by the substrate [26,27]. Milosevic et al. $[7,25]$ described that the diffusional limitations had occurred caused by the support (polymer) that reduces the access of the substrate to the active sites of the bound enzyme. Further, Milosevic et al. [6] explained that the immobilization process interferes with the enzyme catalytic site and/or by diffusional problems generally produced when immobilized enzymes are acting on macromolecular substrates.

Compared with other carriers, the glucoamylase immobilised on the MCF silica (9.2T-3D) had better specific activity. The functionalised magnetic nanoparticles having larger diameter $(<30 \mathrm{~nm})$ obtained the specific activity as high as of 1,408.6 U.g-1 [18]. The mesoporous carbons, which had relatively higher surface area as described above, only gave the specific activity of 84-540 U.g-1 [4,24]. Although the poly(GMAco-EGDMA) had higher pore sizes, the glucoamylase immobilised on this support showed lower specific activity (700-1,100 U.g-1) $[6,25]$, which could be caused by this support had lower surface area than the MCF silica.

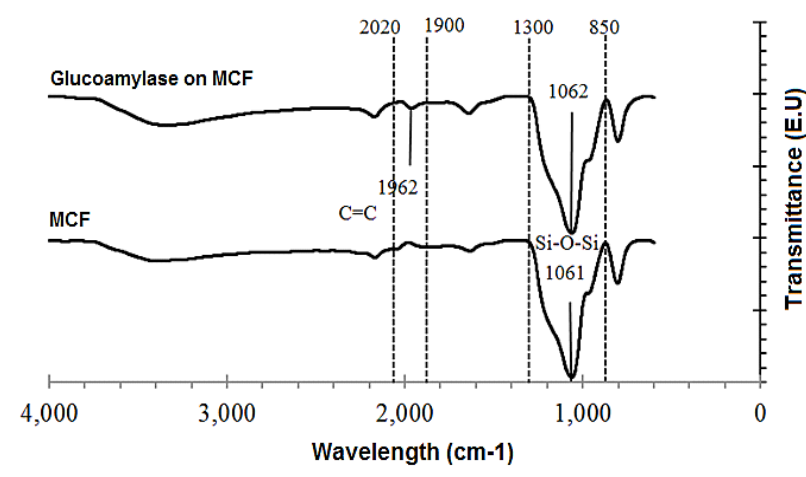

Figure 2. The FTIR spectra 


\subsection{Statistical DOE}

DE values produced by the CCD from combination of 3 (three) operational factors in 5 (five) levels were found in the range of $1.740-76.303 \%$ $(\mathrm{w} / \mathrm{w})$ as shown in Table 2 . The highest result was obtained at $\mathrm{pH}$ of 4.1 , temperature of $70^{\circ} \mathrm{C}$ and agitation speed of $140 \mathrm{rpm}$, whilst the lowest response was observed at temperature of $61.6^{\circ} \mathrm{C}, \mathrm{pH}$ of 4.6 and agitation speed of 140 rpm. To obtain the optimised model and its justifications, the experimental results were processed with Design Expert ${ }^{\circledR}$ v. 6.0.6 software.

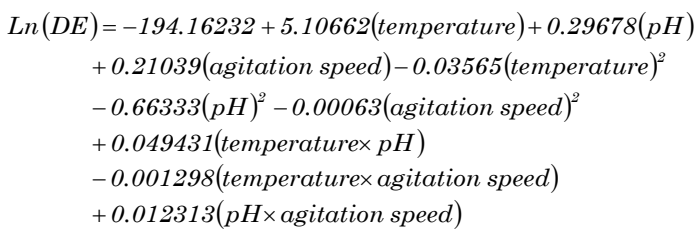

A polynomial quadratic model, which related all operational factors and their interactions, was developed by the statistical analysis as described in Equation (2). As described, all individual factors have positive effects on $\mathrm{DE}$,

Table 2. Central composite design experiments

\begin{tabular}{cccccc}
\hline \multirow{2}{*}{ Run } & $x_{1}$ & & $x_{3}$ & \multicolumn{2}{c}{ DE (\%) (w/w) } \\
\cline { 5 - 6 }$\left({ }^{\circ} \mathrm{C}\right)$ & $x_{2}$ & $(\mathrm{rpm})$ & Actual & Predicted \\
\hline 1 & 61.6 & 4.6 & 140 & 1.740 & 1.42 \\
2 & 65 & 4.9 & 150 & 8.243 & 9.55 \\
3 & 70 & 4.6 & 140 & 68.406 & 68.72 \\
4 & 75 & 4.9 & 150 & 44.830 & 48.79 \\
5 & 70 & 4.6 & 157 & 64.161 & 58.05 \\
6 & 75 & 4.3 & 130 & 71.169 & 68.84 \\
7 & 70 & 5.1 & 140 & 51.852 & 42.41 \\
8 & 75 & 4.3 & 150 & 59.985 & 56.74 \\
9 & 70 & 4.6 & 140 & 68.406 & 68.72 \\
10 & 70 & 4.1 & 140 & 76.303 & 79.43 \\
11 & 75 & 4.9 & 130 & 49.602 & 51.06 \\
12 & 70 & 4.6 & 140 & 68.406 & 68.72 \\
13 & 78.4 & 4.6 & 140 & 20.598 & 21.44 \\
14 & 65 & 4.3 & 150 & 13.725 & 14.94 \\
15 & 70 & 4.6 & 140 & 68.406 & 68.72 \\
16 & 65 & 4.3 & 130 & 13.580 & 13.98 \\
17 & 70 & 4.6 & 140 & 68.406 & 68.72 \\
18 & 70 & 4.6 & 123 & 60.612 & 57.05 \\
19 & 65 & 4.9 & 130 & 6.508 & 7.71 \\
20 & 70 & 4.6 & 140 & 68.406 & 68.72 \\
\hline & & & & &
\end{tabular}

but most quadratic forms show the opposite effects. Temperature and $\mathrm{pH}$ of buffer were the significant factor as their $(P>F)$ values were less than 0.05 (Table 3).

The obtained model is reliable and can be applied to simulate the process. It can describe relationship between response and factorial interactions during the enzymatic hydrolysis process with the $(P>F)$ value is $<0.0001$ (Table 3 ). The lack-of-fit test indicates that the model has insignificant lack-of-fit and a low standard deviation value (i.e. 0.13). Analysis of variance (ANOVA) produces coefficient of determination $\left(R^{2}\right)$ of $99.20 \%$ with the adjusted and predicted $R^{2}$ are $98.48 \%$ and $93.93 \%$, respectively. The $R^{2}$ is acceptable as the closer the $R^{2}$ value to unity, the better the models fits the data [28,29]. Previous observations on polysaccharides hydrolysis using CCD gave the $R^{2}$ of 86.3696.94\% [30-33]. Based-on the resulted $R^{2}$, more

Table 3. Statistical analysis of the model

\begin{tabular}{|c|c|c|c|c|c|}
\hline & Source & $\begin{array}{l}\text { Sum of } \\
\text { Squares }\end{array}$ & $\mathrm{DF}$ & $\begin{array}{c}\text { Mean } \\
\text { Squar } \\
\mathrm{e} \\
\end{array}$ & $\begin{array}{c}\mathrm{p} \text {-value } \\
\text { Prob }> \\
\mathrm{F} \\
\end{array}$ \\
\hline \multirow{7}{*}{ 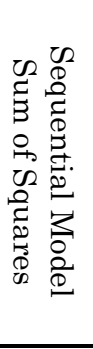 } & Mean & 250.33 & 1 & 250.33 & \\
\hline & Linear & 9.36 & 3 & 3.12 & 0.0217 \\
\hline & $2 \mathrm{FI}$ & 0.089 & 3 & 0.030 & 0.9916 \\
\hline & Quadratic & 11.47 & 3 & 3.82 & $<0.0001$ \\
\hline & Cubic & 0.10 & 4 & 0.026 & 0.1619 \\
\hline & Residual & 0.065 & 6 & 0.011 & \\
\hline & Total & 271.41 & 20 & 13.57 & \\
\hline \multirow{5}{*}{ 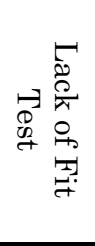 } & Linear & 11.72 & 11 & 1.07 & \\
\hline & $2 \mathrm{FI}$ & 11.64 & 8 & 1.45 & \\
\hline & Quadratic & 0.17 & 5 & 0.034 & \\
\hline & Cubic & 0.065 & 1 & 0.065 & \\
\hline & Pure Error & 0.000 & 5 & 0.000 & \\
\hline \multirow{14}{*}{ 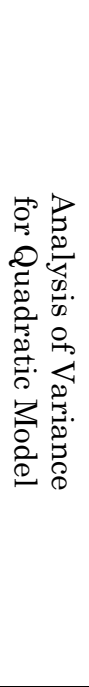 } & Model & 20.91 & 9 & 2.32 & $<0.0001$ \\
\hline & $x_{1}-\mathrm{T}$ & 8.88 & 1 & 8.88 & $<0.0001$ \\
\hline & $x_{2}-\mathrm{pH}$ & 0.48 & 1 & 0.48 & $<0.0003$ \\
\hline & $x_{3}$-rpm & 0.0004 & 1 & 0.0004 & 0.8859 \\
\hline & $x_{1} x_{2}$ & 0.044 & 1 & 0.044 & 0.1369 \\
\hline & $x_{1} x_{3}$ & 0.034 & 1 & 0.034 & 0.1874 \\
\hline & $x_{2} x_{3}$ & 0.011 & 1 & 0.011 & 0.4392 \\
\hline & $x_{1}^{2}$ & 11.45 & 1 & 11.45 & $<0.0001$ \\
\hline & $x_{2}^{2}$ & 0.051 & 1 & 0.051 & 0.111 \\
\hline & $x_{3}{ }^{2}$ & 0.057 & 1 & 0.057 & 0.0961 \\
\hline & Residual & 0.17 & 10 & & \\
\hline & Lack of Fit & 0.17 & 5 & & \\
\hline & Pure Error & 0.000 & 5 & & \\
\hline & Cor Total & 21.08 & 19 & & \\
\hline
\end{tabular}




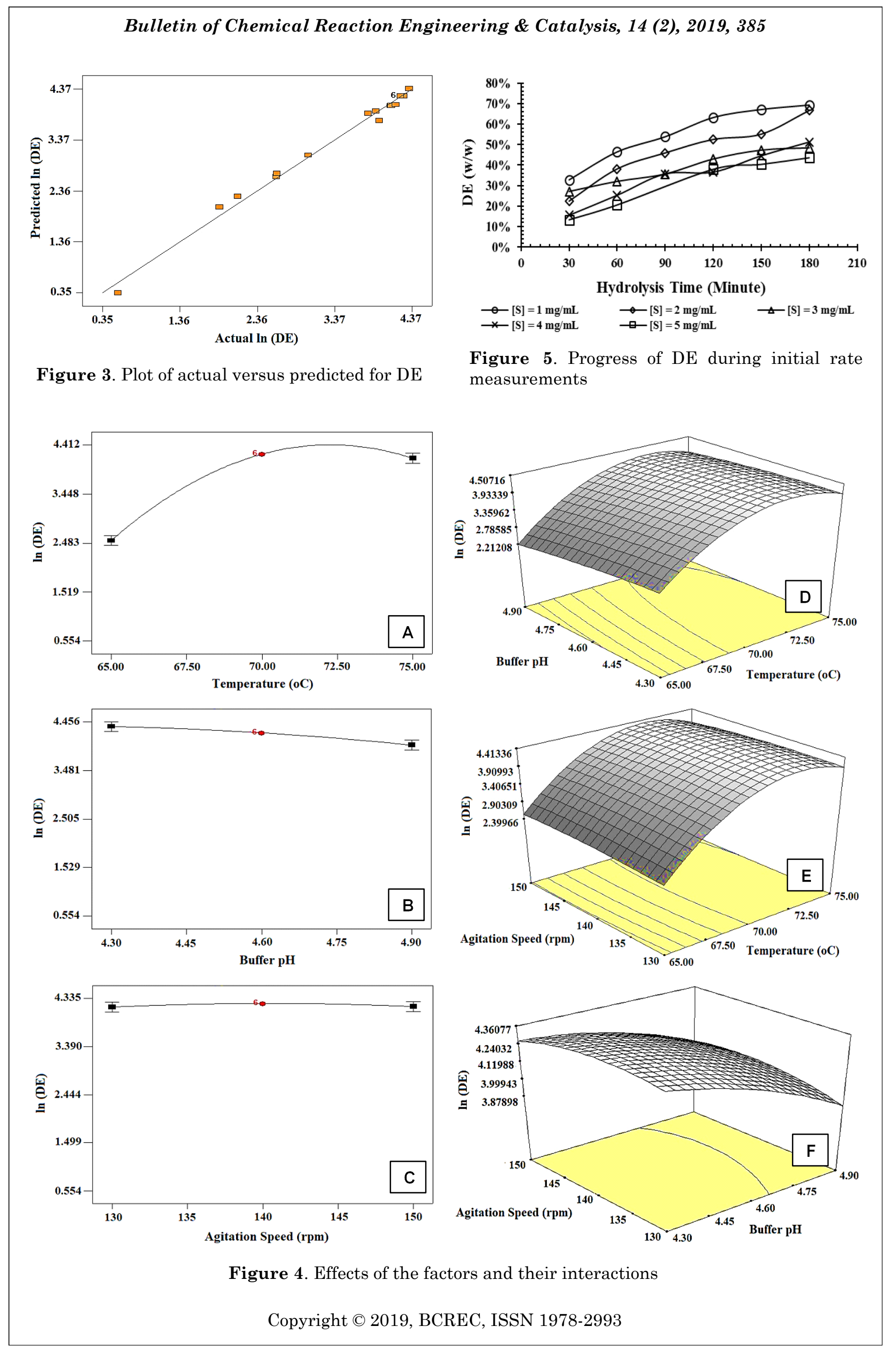


than $95 \%$ of actual data can be explained by the model [34]. Only $0.80 \%$ of total variations were not described by the model. Hence, the predicted responses match the experimental results reasonably well as shown in Figure 3.

\subsection{Effect of Operational Factors}

Factor of temperature affected the process highly as shown in Figure 4-A. Great increases of the response were observed up to temperature of $70{ }^{\circ} \mathrm{C}$ to reach a peak at $72.5^{\circ} \mathrm{C}$, but the effects of the factor were relatively low starting from temperature of $70{ }^{\circ} \mathrm{C}$ to $72.5{ }^{\circ} \mathrm{C}$. Decreases of the $\mathrm{DE}$ values occurred at temperatures of more than $72.5{ }^{\circ} \mathrm{C}$, hence it is not required to operate the process above it. Compared with previous studies, the optimum temperature found in the experiments showed different behaviours. Free glucoamylase immobilised on activated carbon, bulk catalytic filamentous carbon, Sibunit and polymeric supports worked optimally at slightly lower operational temperatures i.e. $65-70{ }^{\circ} \mathrm{C}[4,6,7,24,25]$. The same sit- uation was observed on the immobilised glucoamylase on magnetic chitosan nanocarriers where the optimal temperature was $65^{\circ} \mathrm{C}$ [19]. Zhao et al. [21,22] concluded that the optimum temperatures for the glucoamylase on magnetic carbon and clays were between $55^{\circ} \mathrm{C}$ and 65 ${ }^{\circ} \mathrm{C}$. However, immobilisation of the free glucoamylase on ordered mesoporous silica supports operated optimally at temperatures of 30 $40{ }^{\circ} \mathrm{C}$ during hydrolysis of $3 \%(\mathrm{w} / \mathrm{v})$ soluble starch at $\mathrm{pH}$ of 5.5 [16]. This big difference related to the changing of the physical and chemical properties of the enzyme during the immobilisation process where the creation of conformational limitations on the movement of the enzyme as a consequence of the formation of covalent bonds between the enzyme and the support [6,7].

Although $\mathrm{pH}$ of buffer solution tended to decrease the response (DE) as shown in Figure 4$\mathrm{B}$, its effects were considered quite high as the differences of $\mathrm{DE}$ value found at the low $\mathrm{pH}$ condition (i.e. $71.169 \%$ ) and high $\mathrm{pH}$ condition (i.e. $49.602 \%$ ) were more than $20 \%$. In the ex-
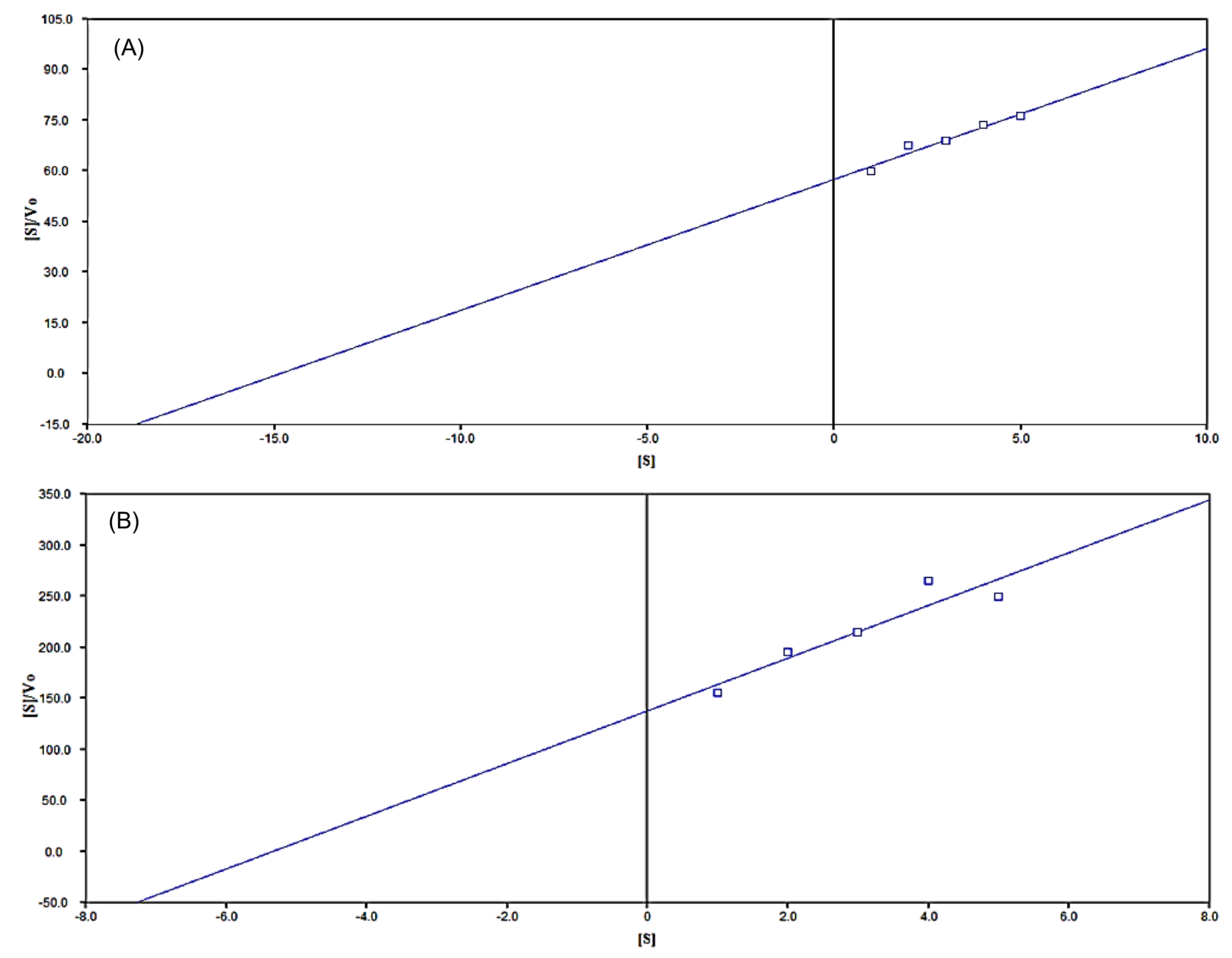

Figure 6. Plot of the kinetics (A: Free enzyme; B: Immobilised enzyme) 
periments, the maximum $\mathrm{DE}$ was found at $\mathrm{pH}$ of 4.30 , however, the $\mathrm{pH}$ of 4.6 gave the $\mathrm{DE}$ value as high as $68.406 \%$, which differed slightly with the maximum value. Hence, operations of the hydrolysis process in the range of 4.3-4.6 were tolerable. The $\mathrm{pHs}$ found in this process were following some earlier observations. The maximum glucoamylase activity immobilised in the supports as described before were discovered at $\mathrm{pH}$ of $4.5[6,7,18,25]$. The cassava maltodextrin hydrolysis using the glucoamylase immobilised on chicken bones worked highly in sodium acetate buffer $\mathrm{pH}$ of 4.5 [35]. Kovalenko and Perminova [4] and Kovalenko et al. [24] concluded that the free glucoamylase from several manufacturers has the optimum $\mathrm{pH}$ of 4.5-4.6, however, from their immobilised glucoamylase experiments, the obtained $\mathrm{pH}$ range was 4.5-5.0 in dextrin hydrolysis. They suspected that the purity of the utilized enzyme related to the $\mathrm{pH}$ change. However, a higher $\mathrm{pH}$ range for immobilised glucoamylase was also observed. The free glucoamylase immobilised in ordered mesoporous silicas and carboxyl-functionalised magnetic nanoparticles had optimum $\mathrm{pHs}$ of $>5.5[2,16]$.

Factor of the agitation speed and the factorial interactions are considered low and not significant matters. The DE values were almost constant during variation of the agitation speed (Figure 4-C). A high DE value (71.169\%) was given by the low agitation speed (i.e. $130 \mathrm{rpm}$ ), whilst the high speed produced the $\mathrm{DE}$ value as high as $59.985 \%$. The speed of $140 \mathrm{rpm}$ developed the DE value of up to $68.406 \%$, which did not differed highly with the speed of $130 \mathrm{rpm}$. Hence the speeds of 130-140 rpm were tolerable during the process operations. Three interactions in the process, i.e. temperature-buffer $\mathrm{pH}\left(x_{1} x_{2}\right)$, temperature-agitation speed $\left(x_{1} x_{3}\right)$ and buffer $\mathrm{pH}$-agitation speed $\left(x_{2} x_{3}\right)$ (Figure 4$\mathrm{D}$ to $\mathrm{F})$, gave the $(\mathrm{P}>\mathrm{F})$ values of $>10 \%$.

From the above descriptions, it is known that the temperature factor affected the immobilised glucoamylase activity highly as it increased the DE rapidly from the low temperature condition within a low temperature range, whilst the $\mathrm{pH}$ of buffer solution developed less high effects on the tapioca hydrolysis process. Both factors indeed were significant for the polynomial process model as described in the previous section. However, the agitation speed has relatively low effects on the process, hence it was concluded as a non-significant factor. These results followed most of the previous studies as mentioned above where 2 (two) important factors were frequently observed during the glucoamylase activity evaluation i.e. temperature and $\mathrm{pH}$ of buffer in which the temperature factor usually worked at a broad range of operational conditions than the $\mathrm{pH}$ factor. Hence, the temperature plays a high role during the enzymatic hydrolysis process of tapioca starch using immobilised glucoamylase on MCF silica as concluded in Table 3.

\subsection{Model Verification}

To observe similarity between the experimental and predicted DE, justification of the model was conducted by testing some proposed solutions provided by the software. The results are shown in Table 4. Differences between both $\mathrm{DE}$ were less than $5 \%$, which are acceptable as they are in the range of $95 \%$ confidence level. This comparison confirmed validity and adequacy of the model.

\subsection{Reaction Kinetics}

The enzymatic kinetics data were determined by observing the reaction progress at tapioca concentrations of $1-5 \mathrm{mg} \mathrm{mL}-1$ in 30 minutes time interval for 3 (three) hours as drawn in Figure 5. All concentrations almost have the same reaction rates. In the first 30 minutes, $13-32 \%(\mathrm{w} / \mathrm{w})$ DE were formed where higher tapioca concentrations tended to give low $\mathrm{DE}$ values. After 120 minutes, $\mathrm{DE}$ values were increased to $36.55-63.18 \%(\mathrm{w} / \mathrm{w})$ indicating the active sites of the immobilised glucoamylase were not difficult to be accessed by the substrate. At least more than $45 \%(w / w) ~ D E$ were obtained after 3 hours.

Table 4. The actual DE versus predicted DE

\begin{tabular}{ccccccc}
\hline \multirow{2}{*}{ Solution } & $\begin{array}{c}\text { Temperature } \\
\left({ }^{\circ} \mathrm{C}\right)\end{array}$ & $\begin{array}{c}\text { Buffer } \\
\mathrm{pH}\end{array}$ & $\begin{array}{c}\text { Agitation Speed } \\
(\mathrm{rpm})\end{array}$ & \multicolumn{3}{c}{ \%DE } \\
\cline { 5 - 7 } & 66.7 & 4.1 & 127 & 31.78 & 34.90 & 3.12 \\
2 & 72.4 & 4.3 & 137 & 91.84 & 90.12 & -1.72 \\
3 & 73.5 & 4.3 & 129 & 84.86 & 88.53 & 3.67 \\
4 & 73.2 & 4.6 & 143 & 78.65 & 75.78 & -2.87 \\
\hline
\end{tabular}


$K_{M}$ and $V_{\max }$ value calculation were based-on Michaelis-Menten equation (Equation (3)). The formula was analysed using Hanes-Woolf plot (Equation (4)) as it gives low deviations from true $K_{M}$ and $V_{\max }$ [36]. The errors resulted by this plot are distributed more evenly than the Linewaver-Burk and Eadie-Hoftsee plot [37].

$$
\begin{gathered}
v=\frac{V_{\max }[S]}{K_{M}+[S]} \\
\frac{[S]}{v}=[S]\left(\frac{1}{V_{\max }}\right)+\frac{K_{M}}{V_{\max }}
\end{gathered}
$$

where $v$ is rate of reaction, $K_{M}$ is the MichaelisMenten constant, $V_{\max }$ is the maximum reaction rate and $[S]$ is concentration of substrate. Figure 6 describes the Hanes-Woolf plot for both glucoamylase types.

Value of $K_{M}$ for the immobilised glucoamylase is lower than the free enzyme. The immobilised type had the $K_{M}$ value of $5.33 \mathrm{mg} \cdot \mathrm{mL}^{-1}$, whilst the $K_{M}$ for the free glucoamylase was $14.86 \mathrm{mg} . \mathrm{mL}^{-1}$. The increase of the $K_{M}$ value after the immobilisation indicated that the enzyme had better affinity on the substrate. This could be caused by the change of the enzyme structure that increased the accesability of the enzyme active sites [38]. $V_{\max }$ for the process catalyzed by the immobilised and free glucoamylase were 0.04 and $0.26 \mathrm{mg}^{-1} \cdot \mathrm{mL}^{-1}$. minute ${ }^{-1}$, respectively. Although $82 \%$ of free glucoamylase was adsorbed by the support, the specific activity of the immobilised enzyme was lower than the free type meaning reduction of the free glucoamylase activity indeed occurred after the immobilisation process as described previously. The glucoamylase immobilised on MCF silica (9,2T-3D) had similar $V_{\max }$ value with the glucoamylase encapsulated by calcium-alginateclay in tapioca starch hydrolysis, but the $K_{M}$ result indicated that this siliceous support was more resistance. Rahim et al. [12] obtained the $V_{\max }$ and $K_{M}$ of $0.0762 \mathrm{mg} \cdot \mathrm{mL}^{-1}$.minute ${ }^{-1}$ and $2.1708 \mathrm{mg} \cdot \mathrm{mL}^{-1}$, respectively, whilst their free glucoamylase gave the $V_{\max }$ and $K_{M}$ of 0.2247 mg.mL $\mathrm{mL}^{-1} \cdot \mathrm{minute}^{-1}$ and $1.8326 \mathrm{mg} \cdot \mathrm{mL}^{-1}$, which were better than the free glucoamylase used in the experiments.

\section{Conclusion}

Immobilisation of glucoamylase on MCF silica $(9.2 \mathrm{~T}-3 \mathrm{D})$ gave up to $82 \%$ efficiency with the immobilised enzyme specific activity of $1,856.78 \mathrm{U} . \mathrm{g}^{-1}$. Its uses to hydrolysis of tapioca starch resulted DE values of 1.740-76.303\% (w/w) where the highest DE was obtained at $\mathrm{pH}$ of 4.1 , temperature of $70{ }^{\circ} \mathrm{C}$ and agitation speed of $140 \mathrm{rpm}$. The statistical optimisation of the process produced a polynomial quadratic model, which has insignificant lack-of-fit and low standard deviation, so that it is applicable and reliable in simulating the results in which only $0.80 \%$ of the data were not described. Temperature affected the process highly, but the buffer $\mathrm{pH}$, agitation speed and factorial interactions were considered not important. $K_{M}$ value for immobilised enzyme was better than the free glucoamylase, however, its reaction rate was slower than the free glucoamylase catalysis.

\section{Acknowledgement}

The financial support from Universitas Lampung via The Superior Reasearch Grant (Hibah Penelitian Unggulan No. 270/UN26.21.PN/2017) was deeply acknowledged.

\section{References}

[1] Wu, Z., Qi, W., Wang, M., Wang, Y., Su, R., He, Z. (2013). Chelate immobilization of amylase on metal ceramic powder: Preparation, characterization and application. Biochemical Engineering Journal, 77: 190-197.

[2] Guo, C., Yunhui, M., Pengfei, S., Baishan, F. (2012). Direct binding glucoamylase onto carboxyl-functioned magnetic nanoparticles. Biochemical Engineering Journal, 67: 120-125.

[3] Zhao, G., Wang, J, Li, Y, Huang, H., Chen, X. (2012). Reversible immobilization of glucoamylase onto metal-ligand functionalized magnetic FeSBA-15. Biochemical Engineering Journal, 68: 159-166.

[4] Kovalenko, G.A., Perminova, L.V. (2008). Immobilization of glucoamylase by adsorption on carbon supports and its application for heterogeneous hydrolysis of dextrin. Carbohydrate Research, 343: 1202-1211.

[5] Sanjay, G., Sugunan, S. (2005). Glucoamylase immobilized on montmorillonite: Synthesis, characterization and starch hydrolysis activity in a fixed bed reactor. Catalysis Communic a tion, 6 : $525-530$. doi:10.1016/j.catcom.2005.04.016

[6] Milosavić, N.B., Prodanović, R.M., Jovanović, S.M., Vujčić, Z.M. (2007). Immobilization of glucoamylase via its carbohydrate moiety on macroporous poly(GMA-co-EGDMA). Enzyme Microbial Technology, 40: 1422-1426. doi: 10.1016/j.enzmictec. 2006.10.018

[7] Milosavić, N.B., Prodanović, R.M., Jovanović, S.M., Vujčić, Z.M. (2004). Immobilisation of glucoamylase on macroporous spheres. APTEFF, 35: 207-214. 
[8] Torres, R., Pessela, B.C., Mateo, C., Fuentes, C.M., Guisan, J.M., Fernandez-Lafuente, R. (2004). Reversible immobilization of glucoamylase by ionic adsorption on sepabeads coated with polyethyleneimine. Biotechnology Progress. 20: 1297-1300. doi:10.1021/bp049943g

[9] Kamal, H., Sabry, G.M., Lofty, S., Abdallah, N.M., Rosiak, J., El-Sayed, A.H. (2008). Immobilization of glucoamylase on polypropylene fibers modified by radiation induced graft copolymerization. Journal of Macromolecular Science Part A: Pure and Applied Chemistry, 45: 65-75. doi: 10.1080/10601320701683322

[10] Wu, Y.G., Sun, W.T., Wang, S.T., Zhou, H., Li, W. (1998). Preparation and stability of glucoamylase immobilized on porous starch graft copolymer beads. Chemistry Journal of Chinese University, 19: 1346-1348. doi:10.1016/S0141-0229(00)00232-5

[11] Tanriseven, A., Olcer, Z. (2008). A novel method for the immobilization of glucoamylaseonto polyglutaraldehyde-activated gelatin. Biochemical Engineering Journal, 39: 430434. doi:10.1016/S0141-0229(02)00004-2

[12] Rahim, S.N.A., Sulaiman, A., Hamid, K.H.K., Rodhi, M.N.M., Musa, M., Hamzah, F., Edama, N.A. (2013). Nanoclay supporting materials for enzymes immobilization: kinetics investigation of free and immobilized system. Applied Mechanics and Materials, 393: 115120.

doi:10.4028/www.scientific.net/AMM.393.115

[13] Oros, B.V., Preda, G, Dudas, Z, Dragomirescu, M., Chiriac, A. (2007). Entrapment of glucoamylase by sol-gel technique in PhTES/TEOS hybrid matrixes. Processing and Application of Ceramics, 1: 63-67. doi:10.2298/PAC0702063V

[14] Szymanska, K., Bryjak, J., Mrowiec-Białon, J., Jarzebski, J.B. (2007). Application and properties of siliceous mesostructured cellular foams as enzymes carriers to obtain efficient biocatalysts. Microporous Mesoporous Materials. 99: 167-175

doi:10.1016/j.micromeso.2006.08.035

[15] George, R., Sugunan, S. (2014). Kinetic and thermodynamic parameters of immobilized glucoamylase on different mesoporous silica for starch hydrolysis: a comparative study. Journal of Molecular Catalysis B: Enzymatic, 106: 81-89. doi:10.1016/ j.molcatb.2014.04.016

[16] George, R., Gopinath, S., Sugunan, S. (2013). Improved stabilities of immobilized glucoamylase on functionalized mesoporous silica synthesized using decane as swelling agent. Bulletin of Chemical Reaction Engineering and Catalysis, 8: 70-76.

doi:10.9767/bcrec.8.1.4208.70-76
[17] Hermida, L., Abdullah, A.Z., Mohamed, A.R. (2013). Nickel functionalized mesostructured cellular foam (mcf) silica as a catalyst for solventless deoxygenation of palmitic acid to produce diesel-like hydrocarbons. In: MendezVilas, A. ed. Materials and Processes for Energy: Communicating Current Research and Technological Development. Ed. Formatex Research Center C/ Zurbarán 1, 2, Oficina 1 06002. Badajoz Spain.

[18] Panek, A., Pietrow, O., Synowiecki, J. (2012). Characterization of glucoamylase immobilized on magnetic nanoparticles. Starch/Starke, 00: 1-6.

[19] Wang J., Zhao, G., Li, Y., Liu, Y., Hou, H. (2013). Reversible immobilization of glucoamylase onto magnetic chitosan nanocarriers. Applied Microbiology and Biotechnology. 97: 681-692. doi:10.1007/s00253-012-3979-2

[20] Ma, Y.X., Li, Y.F., Zhao, G.H., Yang, L.Q., Wang, J.Z., Shan, X., Yan, X. (2012). Preparation and characterization of graphite nanosheets decorated with $\mathrm{Fe}_{3} \mathrm{O}_{4}$ nanoparticles used in the immobilization of glucoamylase. Carbon, 50: 2976-2986.

[21] Zhao, G., Li, Y., Wang, J., Zhu, H. (2011a). Reversible immobilization of glucoamylase onto magnetic carbon nanotubes functionalized with dendrimer. Applied Microbiology and Biotechnology, 91: 591-60. doi: 10.1007/s00253-011-3299-y

[22] Zhao, G., Wang, J., Li, Y., Chen, X., Liu, Y. (2011b). Enzymes Immobilized on Superparamagnetic $\mathrm{Fe}_{3} \mathrm{O}_{4} @$ Clays Nanocomposites: Preparation, Characterization, and a New Strategy for the Regeneration of Supports. Journal of Physical Chemistry C, 115: 63506359. doi: 10.1021/jp200156j

[23] Fayer, M.D., ed. (2013). Ultrafast Infrared Vibrational Spectroscopy. New York: CRC Press.

[24] Kovalenko, G.A., Perminova, L.V., Terent'eva, T.G., Plaksin, G.V. (2007). Catalytic Properties of Glucoamylase Immobilized on Synthetic Carbon Material Sibunit. Applied Biochemistry and Microbiology, 43: 374378. doi: 10.1134/ S0003683807040023

[25] Milosavić, N.B., Prodanović, R., Jovanović, S., Novakovic, I., Vujčić, Z. (2005). Preparation and characterization of two types of covalently immobilized amyloglucosidase. J. Serb. Chem. Soc. 70(5) 713-719.

[26] Dwevedi, A. (2016). Basic of enzyme immobilization. Switzerland: Springer International Publishing.

[27] Butterfield. D.A., Bhattacharyya, D., Dannert, S., Bachas, L. (2001). Catalytic biofunctional membranes containing site-specifically 
immobilized enzyme arrays. Journal of Membran Science, 181: 29-37. doi: 10.1016/S03767388(00)00342-2

[28] Cao, W., Zhang, C., Hong, P., Ji, H. (2008). Response surface methodology for autolysis parameters optimization of shrimp head and amino acids released during autolysis. Food Chemistry, 109: 176-183. doi: 10.1016/j.foodchem.2007.11.080

[29] Tan, I.A.W., Ahmad, A.L., Hameed, B.H. (2008). Preparation of activated carbon from coconut husk: optimization study on removal of 2,4,6 trichlorophenol using response surface methodology. Journal of Hazardous $M a$ terials, 153: 709-717.

[30] Mudgil, D., Sheweta, B., Khatkar, B.S. (2012). Optimization of enzymatic hydrolysis of guar gum using response surface methodology. Journal of Food Science and Technology, 51: 1600-1605. doi: 10.1007/s13197-012-0678-z

[31] Collares, R.M., Miklasevicius, L.V.S., Bassaco, M.M., Salau, N.P.G., MAzutti, M.A., Bisognin, D.A., Terra, L.M. (2012). Optimization of enzymatic hydrolysis of cassava to obtain fermentable sugars. Journal of Zhejiang University Science $B, \quad$ 13: 579-586. doi: 10.1631/jzus.B1100297

[32] Nadir, N., Mel, M., Karim, M.I.A., Yunus, R.M. (2010). Optimisation of hydrolylis conditions for ethanol production from surgom starch. Journal - The Institution of Engineers Malaysia, 71: 26-34.
[33] Peatciyammal, N., Balachandar, B., Kumar, M.D., Tamilarasan, K., Muthukumaran, C. (2010). Statistical optimization of enzymatic hydrolysis of potato (solanum tuberosum) starch by immobilized a-amylase. International Journal of Biological, Biomolecular, Agricultural, Food and Biotechnological Engineering, 4(1): 126-130

[34] Montgomery, D.C. (2001). Design and analysis of experiments. 5th ed. London: John Wiley \& Sons, Inc.

[35] Carpio, C., Escobar, F., Batista-Viera, F., Ruales, J. (2011). Bone-bound glucoamylase as a biocatalyst in bench-scale production of glucose syrups from liquefied cassava starch. Food and Bioprocess Technology, 4:566-577.

[36] Copeland, R.A. (2000). Enzymes: A Practical Introduction to Structure, Mechanism, and Data Analysis, New York: Wiley-VCH, Inc.

[37] Bisswanger, H. (2002). Enzyme Kinetics: Principles and Methods. Weinheim: WileyVCH Verlag GmbH.

[38] Bayramoglu, G., Yilmaz, M., Arica, M.Y. (2004). Immobilization of a thermostable alfa amylase onto reactive membrans: Kinetics Characterization and Application to Continuous Starch Hydrolysis. Journal of Food Chemistry, 84: 591-599. 